\title{
The Impact of Using Email on Improving the Writing Skills Among Iranian Students
}

\author{
Abusaied Janfaza (Corresponding Author) \\ Department of English Language, Javid university, Jiroft, Iran \\ E-mail: s_janfaza@hotmail.com \\ Khadijeh Shahsavari \\ Department of English Language and Literature Larestan \\ Branch, Islamic Azad University, Larestan, Iran \\ E-mail: khadijehshahsavari@yahoo.com \\ Afshin Soori \\ Department of English Language and Literature Larestan \\ Branch, Islamic Azad University, Larestan, Iran \\ E-mail: afshin_soori@yahoo.com
}

Doi:10.7575/aiac.alls.v.5n.5p.75

Received: 19/06/2014

URL: http://dx.doi.org/10.7575/aiac.alls.v.5n.5p.75

Accepted: 15/08/2014

\begin{abstract}
The need for the application of technology in education has been increased. One of the new approaches in technology is using email for learning a second or a foreign language. The present study aimed at investigating the effectiveness of using email in improving writing skills among Iranian EFL students. The participants of the study were 42 preintermediate Iranian EFL students in an English language institute in Shiraz, Iran. The participants were randomly assigned into an experimental and a control group. Each group consisted of 21 participants. The treatment continued for three weeks and 3 sessions a week. The students in the experimental group used email for sending their assignments. These students were in contact with their teacher via email and asked writing questions. In contrast, the students in the control group taught writing without using the computer in traditional way. To be sure of homogeneity of the participants, a pre-test was administered before the treatment. After three weeks treatment, a post-test was administered to check the students' improvement in writing. The findings revealed that the students in in the experimental group performed significantly better than the students in the control group.
\end{abstract}

Keywords: Writing Skill, Electronic Mail, Computer-Assisted language learning, Iranian EFL students

\section{Introduction}

With the advent of technology, the need for the application of this approach in education increased. At present, this new approach is using effectively in different aspects of education. One of the main applications of technology is in language classrooms. Technology has both influenced on the communication among people and has provided more accessibility and more flexibility in the way education can serve people. Today, a large number of educational settings try to motivate their teachers or instructors to implement technology and especially Web and internet in the language classrooms. Email is fairly new technology which is developing worldwide and using this technology is increasing in the classrooms to promote second or foreign language learning and teaching. Although a number of studies have investigated the impact of using email on students' learning, few studies have explored the students' perceptions towards using email and its effectiveness in learning a second or foreign language. Some researchers (e.g. Gunduz 2005) believe that technology in education plays an important role in the last three decades of the 20th century. Gunduz (2005) stated that as working with computers are so easy, and everybody is easily access to the computers and internet, and they are able to store a large amount of data, the application of computers in educational systems have been developing in all over the world. With the application of technology in education, the process of language learning has been drastically changed recently. Computers are not just considered as information processing tools, they are suitable tools for communication. Thus, language learners are able to use this technology to communicate with other speakers of the target language through email. To this end, computers can be suitable for language learner to improve different language skills.

According to Gunduz (2005), language learning materials like charts, newspapers, and etc. have been supplemented by some helpful new technologies like internet and emails. Roschelle, Pea, Hoadley, Gordin, \&Means (2000) referred to four main characteristics of technology that can help students to improve their learning a second language in the classroom. The active engagement is the first characteristic of technology. In fact, children are able to improve their 
learning through constant use of computers in the classroom. The second characteristic refers to using it in groups. In other words, computers can be used individually or in groups. Frequent interaction and feedback is the third characteristic. While learning a second or foreign language with the help of technology, interaction and feedback can play a vital role in promoting language learning. Connection to the real world context is the last characteristics. Roschelle et al., (2000) believed that if teachers integrate internet into classroom, teaching and learning will be developed.

To Warschauer \& Healey (1998), the role of computers in second language learning and teaching is undeniable. Chun (1994, as cited in Shang, 2005) pointed out, "computer mediated communication has many advantages in learning the second language which the important one is to give some chances to be in the interactive language learning and to use the right of the target language" (p.176). Ma (1993) stated that students communicate through emails to share their information. Silva, Meagher, Valenzuela, \& Crenshaw (1996 as cited in Yu \& Jessy, 2001) found that "if students be in contact with linguistically different audiences and give them authentic reasons of their communication in target language; it helps to reach satisfying experience of language learning(p.364). Bordbar (2010) investigated the helpfulness of using computers in a language classroom. In his study, he also explored the teachers' perceptions towards integration computers in classroom and how they use computers in language teaching. He found that there was a relationship between information and communication technology and Iranian society and schools.

Al-saleem (2011) believes that the most usage of computer is email which can be used by any individual in all over the world. Electronic mail (Email) is electronic message which is sent from an individual to another individual. To Alsaleem (2011), Header and Body are two parts of email messages. The header contains "form, To, CC, and subject date, and so on which individuals put necessary information in them but the latter part (Body) included basic content; sometimes a signature block at the end" (p.148). Case (1996) refers to two types of network as locally and globally, and the emails can be sent through these networks. Case (1996) as cited in Niazi \& Pourgharib (2013), believes that "although there are many local area networks and wide area net works from the internet- which send too much messages daily, email is the world's largest computer network which is growing rapidly" (p.3533).

Belisle (1996) refers to numerous advantages of using emails. He believes that both teachers and students take advantage of computers. To this end, he mentions three reasons. First of all, using email in the classroom can help students to improve their language learning. Today, email is using worldwide in business, politics, and technology. Therefore, some traditional tools like paper, and fax communication have been supplemented by emails. Secondly, A teacher is able to interact with students working on a project at more convenient times. The teachers do not have any limitation to interact with their students. However, the interaction between the teacher and the students over a writing task is not limited to classrooms. This interaction can be expanded outside of the classroom. Finally, by using email the teacher can save time for doing some assignments in the classroom. Students can easily receive the assignments sent by teachers. For example, a teacher can send just a message to all the students booked in his/her list to recall them not to forget doing their assignments.

Warschauer (1996) refers to computer-assisted language learning as the most interesting area for teachers, students and researchers. Like most researchers, Warschauer (1996) believes computers play important roles in schools, homes, business, and etc. Therefore, teachers always think deeply about using technology in classrooms. To Jalali \& Ghaznavi (2011) synchronous and asynchronous are two types of communication via internet. In synchronous "people can interact with each other in a simultaneous conversation by using some devices such as Moos and Chat rooms" (Jalali \& Ghaznavi, 2011 as cited in Niazi \& Pourgharib, 2013, p. 3533). In $n$ this type, all the members of a group try to send some information at the same time. The individuals are online and they are sending information. However, in asynchronous communication, there is no need for the individuals to be online simultaneously, but an individual sends an email, and other individuals are allowed to check their emails and answer that email and write their own messages whenever they like (Jalali \&Ghaznavi, 2011).

To Warschauer (2000), email is the mother of all internet applications. Cario(1999) believes that the application of email in the classroom is accompanying with some inevitable problems. However, its application can provide some good opportunities for students to communicate in the target language. Thus, the students are not limited to communicate with their classmates, but they will have some opportunities to communicate with others through sending and receiving messages through emails.

Belisle (1996) points out that an important tool that brings some opportunities for students to communicate with each other in order to exchange information and experiences is email. He also believes that ideas and information can be produced, created and analyzed easier than before. Frizler (1995) states that online writing courses are more effective than traditional writing courses for language learners.He believes that online writing courses are good because they save time, however, it takes time to teach students how to use internet for educational purposes.

Although there are numerous study on the effect of using email technology, there are few studies on the effects of using emails on language learning. Moreover, it seems the studies that have been carried out so far have investigated the effects of emails traditional methods of writing, there are relatively few studies to focus on computer-based writing activities (Toyoda, 2001 cited in Jalali \& Ghaznavi, 2011). Since there are some limitations for learning a second or foreign language like lack of access to native speakers or using excessive use of Persian in language classrooms in Iran, CALL can be a good solution for these limitations. To this end, the researcher tries to investigate the effectiveness of 
using email in improving writing skills among Iranian EFL students. Regarding this issue the research question is as follows:

- $\quad$ Is using email effective in improving the writing skill among Iranian EFL university students?

\section{Methodology}

\subsection{Participants}

The participants of the current study were 42 pre-intermediate Iranian EFL students in an English language institute in Shiraz, Iran. To check for the homogeneity of the students, an Oxford Placement Test was administered. The results of the test revealed that the students were homogeneous. These 42 students were randomly assigned into two groups, an experimental and a control group. They were 16 to 18 years old. A pre-test and a post-test English language writing skill were given to both groups. The students in the experimental group received a treatment on how to create an email and how to send and receive email in English. The students in the control group did not receive any treatment. They were taught in traditional method of writing.

\subsection{Instruments}

To conduct the present study, some instruments were utilized. First, an Oxford Placement Test was administered to all the students to be sure of homogeneity of the students in terms of English language before administering the pre-test. A pre-test and a post-test were given to all the students. The pre-test included grammar, vocabulary, and writing which was prepared by the researcher. The sources of the items for the pre-test were taken from Interchange 1 by Richards (2005). The pre-test was piloted first with the same level of the students from another language institute. The reliability of the test was calculated through Kuder-Richardson formula 21. The result revealed that the reliability was low. To this end, the items were revised and poor items were discarded. The post-test was as the same as the pre-test because the time interval between the pre and the post-test was more than two weeks (Hatch \&Farhady, 1982) that prevented the students from the test wisenss.

\section{Procedure}

In the present study, the researcher administered an Oxford Placement Test to all participants. After analyzing the data, 42 students were selected for this study. The students randomly assigned into an experimental and a control group. All the students in both experimental and control groups were administered a pre-test. The students in the experimental group were explained about the aim of the study. The researcher explained how the email is used in learning a foreign language. The students in the control group didn't receive any treatment related to email training. The design of the study was experimental. All the students were first administered a computer proficiency test, that included computer proficiency levels and some probable difficulties for working with a computer. At the next session, all students were administered a proficiency test with 50 items. The students were given 50 minutes presentation on chapters of Interchange 1. The treatment continued for three weeks and 3 sessions a week. The post-test was the same the pre-test. It was administered to examine how much the students had progressed during the treatment sessions.

\section{Results}

As shown in Table1, the means of experimental and control groups were very close together. The comparison between the mean scores between groups showed that there was no considerable difference between mean scores. Unlike during the pre-test, the comparison between the mean scores among different groups in the post-test revealed that there were considerable differences among mean scores.

Table 1.Descriptive statistics and Independent Sample Test.

\begin{tabular}{llllcc}
\hline \multirow{3}{*}{ Pre-test } & Group & $\mathrm{N}$ & Mean & Std. Deviation & Std. Error Mean \\
& Experimental & 21 & 6.47 & 2.456 & .5432 \\
\multirow{3}{*}{ Post-test } & Control & 21 & 6.33 & 5.135 & .6654 \\
& Experimental & 21 & 17.38 & 3.69 & .8124 \\
& Control & 21 & 22.55 & 3.28 & .7756 \\
\hline
\end{tabular}

As depicted in Table 2, there was a significant difference between the experimental and control groups in pre-test and post-test gain scores. The result also revealed that there was an improvement in learning in experimental group from pre-test to the post-test, and the amount of this improvement was higher in experimental group in comparison to the control group. In addition, the students in the experimental group performed significantly better than the students in the control group. 
Table 2. Independent Samples t-test.

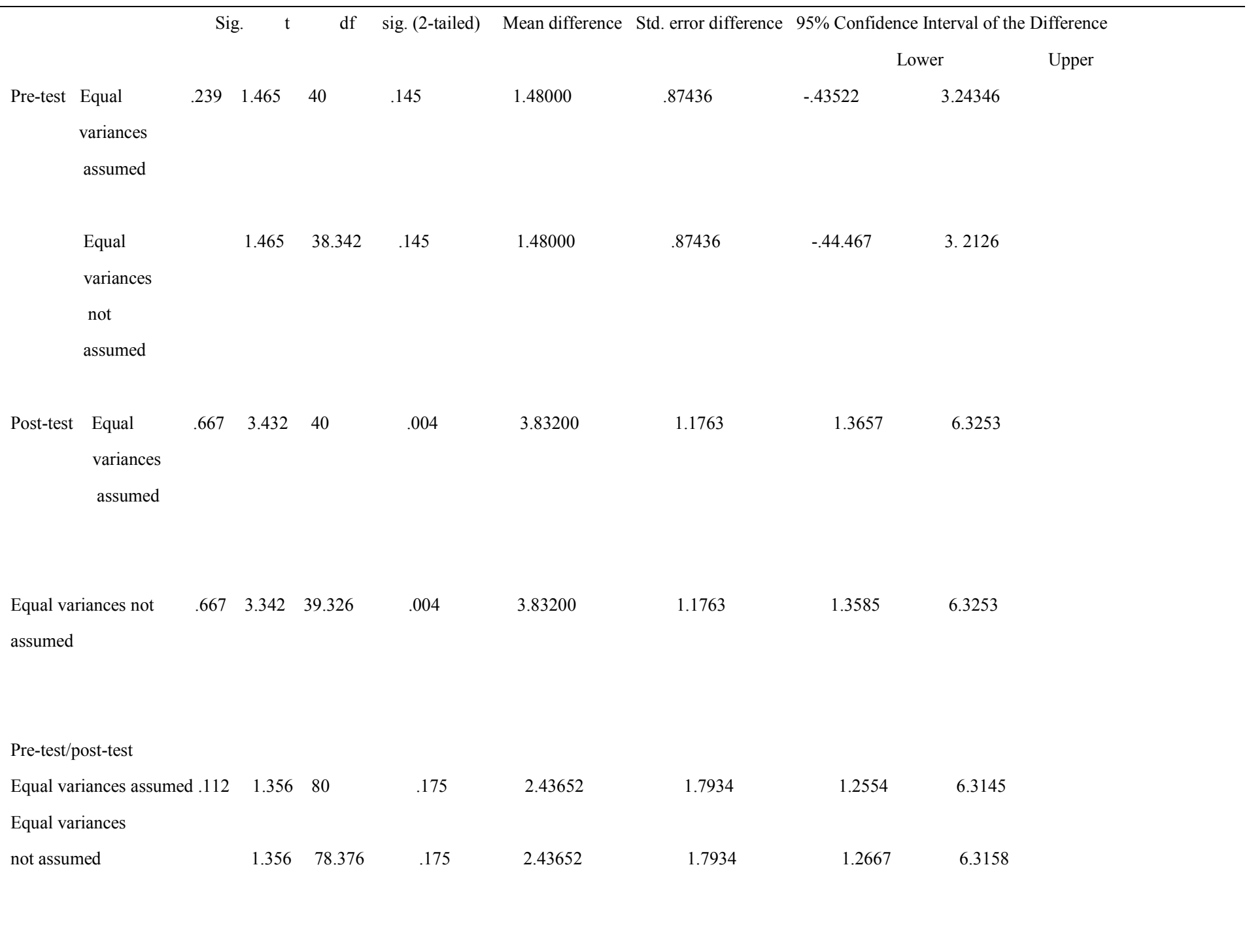

\section{Discussion and Conclusion}

The findings of the current study indicated that use of email had a positive effect on the writing of the students. In addition, in comparison to the traditional method, the students used email had a better performance. One probable reason for better performance refers to constant contact between the teacher and the students via emails. Students were in contact with their teacher via email and asked writing questions, and the teacher replied their emails and guided them to write correctly. Since the teacher was online most of the time, the students had good opportunities to access to their teachers and ask their questions. In contrast, in the other class in which the teacher taught writing in traditional way the students did not have this opportunity to keep in contact with their teachers outside of the classroom. Thus, they didn't have any chance to remove their writing problems outside the classroom and they didn't access their teacher all over the time. The findings of this study was in line with the one by Belisle (1996) and Niazi \& Pourgharib, 2013 who found that the integration of email in writing classroom is effective and improve the writing skills. Belisle (1996) believed that learners are able to create, analyze, and produce information effectively by using net. He also stated that "learning can be transferred from old fashioned passive-listening, teacher-centered activities, to an experience of discovery, exploration, and excitement" (Belisle, 1996 as cited in Niazi \& Pourgharib, 2013,p. 3536) . Other researchers (e.g Corio 1999 and Warschauer 1996) believed that email was effective to enhance writing proficiency. To Warschauer (1996), "the mother of all internet applications" is email. Corio (1999) referred to the applications of emails in classrooms. He believed that email can be the medium of communication in second language (Niazi \& Pourgharib, 2013). By email the students can exchange messages with other individual from all over the world. To this end, they are able to enhance writing ability by using emails.

\section{References}

Al-Saleem, B. (2011).The Impact of the Cross-cultural E-mail Exchange Program to Enhance the EFL Undergraduate Jordanian Students' Writing Skill.Educational Research, 2(6), 1193-1198 .

Belisle, R.(1996). E-mail Activities in the ESL Writing Class. The Internet TESL Journal, Vol. II, No. 12. 
Bordbar, F. (2010).English teachers' attitudes toward computer-assisted language learning. International Journal of Language Studies, 4, (3), 27-54.

Chun, D.(1994). Using Computer Networking to Facilitate the Acquisition of Interactive Competence, System, 22, 1731.

Gunduz, N. (2005). Computer Assisted Language Learning (CALL). Journal of Language and Linguistic Studies, 1(2), 193-214.

Jalali S, and Ghaznavi N. (2011).The Effect of Email on Improving EFL Learners' Written Communication and Autonomy.IACSIT Press, Singapore.

Ma, R. (1993).Computer-Mediated Conversation as a New Dimension of Intercultural Communication between College Students in Taiwan and USA. Paper Presented at the International Conference of Chinese Communication Research and Education, Taipei, Taiwan.

Niazi, F. and Pourgharib, B. (2013). The Effect of Using Email on Enhancing Iranian Intermediate EFL Learners Writing Proficiency. International Research Journal of Applied and Basic Sciences, 4, 11, pp. 3531-3539

Roschelle J, Pea P, Hoadley C, Gordin D, Means B. (2000). Changing How and What Children Learn in School with Computer-Based Technologies. The Future of Children and Computer Technology, 10(2), 132-13.

Silva PU, Meagher ME, Valenzuela M, Crenshaw S. 1996. E-mail: real-life classroom experiences with foreign language. Learning and Learning with Technology, 23(5), 10-12.

Toyoda E. 2001. Exercise of Learner Autonomy in Project-Oriented CALL. CALL-EJ, 2(2), 1-11.

Warschauer M, Healey M, 1998. Computers and Language Learning: an Overview, Language Teaching, 31, 57-71.

Warschauer M. 1996. Computer-Assisted Language Learning: an Introduction. In: S. Fotos (eds.) Multimedia Language Teaching. Tokyo: Logos International. pp. 3-20. 